\title{
Financing Higher Education in the Islamic World Through Waqf (Endowment)
}

\author{
Dr. Mohamed Ibrahim Negasi
}

\begin{abstract}
This study shows the meaning of waqf (endowment), its rule, pillars, and its classifications. Then it discusses in detail the contemporary application of the waqf in the financing of higher education from the Islamic point of view. The contemporary applications of waqf, assimilate cash Waqf (Waqf al-nuqood) that are used to finance the establishment and maintenance of higher education institutions, as well as providing the study and research materials for students and lecturers. It is also applied for endowment of books and software program that are relevant to the research and study. Also the endowment of libraries and equipment needed by laboratories, labs and libraries, as well as endowment of the rehabilitation research centers. The study uses the descriptive, the inductive and the analytical method. Based on the discussions and analyses, the study concluded that Waqf plays an effective and influential role in providing funding for higher education.
\end{abstract}

Keywords: Financing Higher Education in the Islamic World Through Waqf (Endowment)

\section{Introduction}

Waqf was known to ancient civilizations even prior to Islam. For example, the pharos used to allot some money to utilize its dividend for serving the gods, temples, graveyards, and for providing income for priests and servants. Ancient Greeks and Iraqis were also familiar with the Waqf. The Arabs also used Waqf prior to Islam. They were accustomed to having some of their moneys dedicated for clothing the Kabah. In Islam Waqf became known after the Hijrah of the Prophet (S.A.W) to Medina. It is worth mentioning that there is no disagreement among the scholars on this issue. Waqf is considered one of the most important economic sources in Islam, and historically it had played a very significant role in funding educational institutions such as Qur'anic schools, Islamic studies, medicine, history and so on the types of Waqf for these institutions included services such as providing the schools with the educational needs, for example, payment of salaries for the staff, housing, health care and other daily expenses for the students. These services were rendered to the poor and the rich, males and females alike. However, the role of Waqf in the 20th century to provide funds to education in many Muslim countries declined as a result, the educational institutions lack funding nowadays. Therefore, there is a need to revive the role of the Waqf to bridge this gap. This can be done through immovable such as properties and movable assets and cash Waqf, then this Waqf is invested in Shariah compliant investments. The profits of such investments are then spent on high educational institutions in the form of grants for students, salaries for lecturers and administrative staff, as well as establishing new universities and their maintenance, as well as covering other educational needs.

This study, therefore, deals with Waqf in details as well as its practical application in funding Islamic high educational institutions. Finally the study proposes some approaches for overcoming the obstacles that may face this project.

\section{The Concept of Waqf}

waqf linguistically means to withhold and to restrict. ${ }^{1}$ As for the technical meaning, the jurists have differed in defining it. This difference is due to some issues related to the rulings (ạkām) of waqf. This study covers the most important scholarly definitions of waqf:

AbūḤanifah defined waqf as, "withholding a subject matter (asset) to be under the exclusive ownership of the endower (wāqif), and to give in charity its usufruct or dispose of its usufruct to a party chosen by the endower. ${ }^{2}$

1 lbnMandhūr, Muḥammad Mukrim, (1419/1999) Lisān al-'Arab, Beirut: Dārlhyā’ al-Turāth al-'Arabī, 2nd Edition, Vol. 6, p. 163.

2lbn al-Humām, Muhamad 'Abdulwāhid, SharḥFath al-Qadīr, Beirut: Dār al-Kutub al- ilmiyah, 2nd Edition,Vol. 6, p.186. 
Ibn'Arafah defined it as "Giving the usufruct of an asset throughout the duration of its existence with the compulsory requirement of it remaining in the ownership of the benefactor even if symbolically. ${ }^{1}$

The author of Mughni al-Muhtāj definedit as "the restricting of wealth that can be used to derive benefit from it while it remains in its original form in order to restrict its disposal to a permissible avenue". ${ }^{2}$ Al Bahwatī Defined waqf as "An outright owner restricting the usage of some of his wealth that is productive while the original form of the wealth remains intact and at the same time the owner's right to dispose of that wealth isterminated". ${ }^{3}$

Monzer Qahf is one of the modern scholars who defined it as, "A permanent or temporary dedication of some form of wealth with the aim of benefitting from it or from what it produces on a repeated basisand channeling such benefit to any form of private or public charity". ${ }^{4}$

After the presentation of these definitions of waqf, it can be said that the appropriate definition that the author is inclined to is the one that comprises of all the core elements which waqf can be defined by. The core elements are as follows: The endower of the waqf, the beneficiary of the waqf, the subject matter of the waqf, and the objective of the waqf. The definition that the author is inclined to is the definition of Dr. Monzer Qahf but with some minor adjustments. Therefore, waqf is the dedication by the endower a portion of his wealth in order to benefit from it or from what it produces in one of the many forms of righteousness.

\section{The Ruling in Regard to Waqf}

The majority of jurists from Ḥanafī, Mālikī, Shāfi'ī and Ḥanbalī schools of jurisprudence have concluded that waqf is permissible and encouraged ${ }^{5}$. Its permissibility has been established in the Qur'ān, Sunnah and ljmā'. In the Qur'ānthey referred to general verses that encourage charitable giving, volunteering, spending money and doing good. ${ }^{6}$ As for the Sunnah, many ahādīth have been narrated that clearly indicate and prove the permissibility of waqf. Moreover, it has been accurately recorded that the Șahāabah (companions) and Tābi'în (followers) made waqf from their wealth, and none of them condemned the action, so this constitutes a consensus (ljmā) onthe permissibility of the waqf. ${ }^{7}$

\section{The Pillars of Waqf}

The majority of jurists ${ }^{8}$ have agreed that waqf has four pillars. They are the endower of the waqf (wāqif), the beneficiary of the waqf (al-mawqüf'alaīhi), the wealth/ asset being endowed (al-māl al-mawqūf) and the format (șighah). ${ }^{9}$

\section{The Classification of Waqf}

Waqf is classified into three types based on the differences between certain factors that must be considered:

\footnotetext{
1Al-Kharshī, Muhammad 'Abdullah'Alī, (1419/1998) Ḥāshiyat al-Kharshī, Beirut: Dār al-Kutub al- Ílmiyah, 1st Edition, Vol. 7, p. 361. 2Al-Shirbīnī, Muhammad al-Khatīb, (1418/1997) Mughnī al-Muhtāj ilā ma'rifat ma āñ̄ alfaz alminhāj, Beirut: Dār al-ma'rifa, 1st Edition, Vol. 2, p. 485.

3Al-Bahwatī, Mansour Younis, (1416/1996) Sharḥ Muntahā al-Irādāt, Beirut: ‘ālam alkutub, Vol. 2, p.397.

4Qahf, Monzer, Contemporary juristic issues concerning Islamic endowments, p. 21.

5Al-Kāsānī, āaladin Abubakar Mas úod, (1418/1997) Badāi' ‘ al-Șanāił', Beirut: Dār al-Kutub al- îlmiyah, 3thd Edition Vol. 8, p. 391. AlKharshī, Hāshiyat al-Kharshī, Vol. 7, p. 365.

6lbid., Vol. 8, p. 392.

7Al-Jamal, Ahmad Mohamad, (1428) the role of the Islamic waqf system in contemporary economic development, al qāhirah: Dār alsalām, p. 41.

8The Hanfĩs are of the opinion that waqf has one pillar only, which is the form.

9Al-Bahwatī, Kashāf al-Qinā', Vol. 4, p. 239.
} 
First: In terms the aim of the waqf: This type consists of three sub-types: ${ }^{1}$

1. Family Waqf: This sub-type of waqf is dedicated to the endower himself or his offspring or a combination of the two, or a specific person. Besides that it could be used for any philanthropypurpose.

2. Charitable Waqf: This sub-type of waqf is established for charitable purposes such as building schools, mosques and hospitals.

3. Combined/Multi-purpose Waqf: This sub-type of waqf is established for a combined purpose of serving offspring and philanthropy at the same time. This happens in a situation where the endower allocates a portion of the waqfwealth/assetfor his children and at the same time, he endows a portion for the purpose of philanthropy.

Second: waqf in terms of its location: ${ }^{2}$ This branch has two sub-types:

1. Waqf of real estate (immovable assets): This sub-type of waqfrefers to the endowment of wealth/assetthat is immovable and non-transferable from one place to another. ${ }^{3}$ An example of this sub-type is land that has or has not been constructed upon. Waqf of real estate is permissible according to all Muslim jurists.

2. Waqf of movable wealth: This sub-type of waqf refers to anything that is movable and transferable from one place to another without causing a change to its shape and form. ${ }^{4}$

Third: Waqfin terms of itstime duration: ${ }^{5}$ This type has two sub-types:

1.Permanent Waqf: has no specific time duration it is intended for an indefinite purpose. It is permissible according to the consensus of the Muslim jurists.

2. Temporary Waqf: is when the endower of the waqfhas a specified amount of time during which the wealth/asset is endowed. After the specified time ends, the wealth/asset returns to the ownership of the endower.

\section{Contemporary applications of Waqf in financing higher education:}

The financing of education in general and higher education in particular is one of the biggest problems that are faced by the Islamic world due to the high costs of education and the expansion of higher education, owing to the increase in the number of enrolled students in higher education. In fact this has resulted the lower quality in educational institutions due to the high number of students and lack of adequate and appropriate preparations for teaching and research, such as: laboratories, teaching aids, libraries with books and databases, and the non-alignment of outputs to the needs of the institutions.

The main reason for the funding crisis experienced by the institutions of higher education in the Islamic world is that the state is the one that provides the bulk of funding for the high educational process, while the possibilities of the countries of the Islamic world are very limited in which that they do not meet the needs for education, and hence there must be alternative sources of funding that should meet the need for high education, the Waqf can contribute to the provision of a large part of the funding for higher education. This alternative is available only through waqf, and the waqf practice can contribute to the provision of a large part of the funding for higher education. There are many contemporary experiences of university endowments more especially the famous universities around the world, particularly in developed countries such as Harvard University, Yale in USA. Cambridge and Oxford in Britain, Kyoto University in Japan and Melbourne University in Australia.

The higher education institutions in the Islamic world could benefit from the experiences of Western universities in relying on the Waqf to provide a large part of funding in the educational process.

1Al-Mahmadī, \{alī Mohamad yousouf, (1422) understanding waqf and its types, paper presented to the first awqāf conference organized by Umm al-Qura university, Mecca, p. 155.

2Mashhūr, Ni mat 'Abdullatîf, (1997) the effect of waqf in the development of society, alqāhirah: Markaz Salih 'AbdullahKamil, p. 23.

3Al-Thamalī, Abdullah Muslih, cash waqif, see: http://iefpedia.com/arab/?p=20103, (accessed on 12/2/2017) p. 6.

4lbid., p. 7.

5Al-Jamal, the role of the Islamic waqf system in contemporary economic development, p. 26. 
The higher education institutions can be funded through the following methods:

\section{1-Cash Waqf :}

The technical meaning of cash is, "any physically existing thing that can possibly serve the purpose of being a medium of exchange, and a measure of value, and a store of value at the same time. The scholars have differed in terms of the legality of the cash waqf in two opinions:

The First Opinion: The Hanafi and Malikī jurists have ruled that cash waqf is permissible. ${ }^{1}$ Those who hold this opinion draw evidence from the Sunnah, 'urf (customs) and logic.

The Second Opinion: The views of AbūḤanīfa, Abū Yusuf, al-Shāfi'ī, and Ibn al-Ḥājib and IbnShās from the Malikīschool of jurisprudence, considering cash waqf impermissible because benefit cannot be gained from it except by depleting it completely. This is because there is no benefit that can be gained from it except by utilizing it and this contradicts the principle of waqf, which is permanence of the endowed asset ${ }^{2}$. Those who held the opinion that cash waqf is impermissible depended on logical sources of evidence.

The waqf institute can choose one of the following two methods in financing higher education:

The first method: The waqf institute can grow all the cash it has collected by utilizing the various investment modes that are Sharī'ah compliant, such as muḍārabah, mushārakah, ijārahand other modern and contemporary investment modes that have been developed by the Islamic banking sector. The expenses of the beneficiaries will be covered from the profit of the investment only, while the capital of the waqf would remain protected and undiminished. ${ }^{3}$ It is important to note that when investing the waqf funds especially when such funds are in the form of liquid assets, certain investment parameters that have been proposed by some studies, which dealt with the issue of investing the waqf funds should be followed. These parameters are as follows: ${ }^{4}$

a) The investment mechanism must be Sharī ah-compliant.

b) Conducting feasibility studies for the selected investments.

c) Weighing the economic benefit and the social benefit of the investments.

d) Weighing between the risk and return of the investments.

e)Weighting between direct investment and investment through others.

f) Diversification of investment.

The second method: The waqf institute can divide the endowed funds into two portions; a portion that would be invested using the modes of investment mentioned in the first method to ensure the continuity of the waqf, while the second portion would be allocated for the financing of the higher education. ${ }^{5}$ The current study will attempt in the following sections to discuss some proposed practical mechanisms for the financing of Islamic schools. In this regard, the waqf institute can implement one of the following two mechanisms in financing higher education ${ }^{6}$ :

\section{The first mechanism: Donations}

The waqf institution has the option of allocating certain amounts to be donated to the higher education in the form of scholarships. These scholarships should be given to the needy segment of the student population such as the destitute,

1lbn'Abdīn, Mohamad'umar (1419/1998) Rad al-Muhtār'Alā al-Dur al-Mukhtār, Beirut: Dārihya' alturāthal 'arabī, Vol. 6, p. 434. AlKharshī, Hēāshiyat al-Kharshī, Vol. 7, p. 365.

2lbn al-Humām, SharḩFath al-Qadīr, Vol. 6, p. 203; Al-Muțīīi, Mohamad Najỉb, (1415/1995) Takmilat al-Majmū‘, Beirut: Dārihya’ Alturāth al-'arabī, Vol. 16, p. 247. IbnQudāmah, alMaqdisī, (1416/1996) al-Mughnī, Al-qāhirah: Dār Alhādīth, Vol. 6, p. 618

3Al-Zarqā, temporary waqf for the financing of small projects for the poor, p. 15.

4Al-Thamālī, cash waqf, p. 33-36.

5Al-Zarqā, temporary cash waqf, p. 4-5.

6 Umar, the mechanisms of Islamic financing of small projects, p. 52. 
poor and orphan students in addition to overachieving students. These scholarships can cover the tuition fees, housing and living expenses, medical costs and all the teaching necessities. As for the private donations that target the establishment of universities, they should be directed to areas where higher educational institutions are few in number or to areas where they are nonexistent due to the lack of human resources or marginalization arising from political, religious or ethnic conflicts. As for the financing of existing higher educational institutions, it can be done with the aim of enhancing and developing such institutions. For example, the waqf institution can donate an amount of money to build a students' hostel or lecture rooms or computer labs, or constructing new universities or maintaining the hostels, computer labs and lecture rooms. Donations can also be directed towards supporting and financing research and studies that can facilitate the development of higher education.

\section{The second mechanism: benevolent qard}

The waqf institution may not have adequate financial resources to finance the higher education via donations. Therefore, it may resort to financing through the mechanism of benevolent qard for the individuals and institutions that are willing to do that. Financing through the mechanism of benevolent qard differs from the mechanism of financing through donations. Therefore, the waqf institution should follow certain procedures to ensure the full payment of the qard.

\section{2-waqf of books:}

This type of waqf is available for many people to participate because of the low cost of the book in this era, apart from this, it is easy to be found and disseminate. Thus, people can be encouraged to this type of endowment in a variety of ways; such as: Waqif buys a set of useful books, and then he sends certain copies to the libraries in the name of Waqf, or that the author makes an endowment for the copyrights of the book and publishing it to those who want to publish it free of charge, hence he would be endowed the incorporeal rights of the book ${ }^{1}$.

\section{3-waqf of software related to research:}

Some computer programs includes a large number of specialized books, and there is available search machine in these program that enables the researcher to access the information that is looking for accurately. For he who wish to endow this type of program to buy copies of the program, and then provide it to libraries of higher education institutions ${ }^{2}$.

\section{4-waqf of libraries:}

In this kind of endowment, Waqif is going to build a library and provide it with the books that the institutions of higher education need in different field, or the specialization determined by the waqif. As it can be equipped by the means that is going to serve and help the researchers, such as computers, Databases, and search machine ${ }^{3}$.

\section{5-waqf of devices:}

Waqif can endow the computers, or equipment required by the libraries, or specialized workshops, or materials and devices needed by researchers, which can be used by a sample to serve the researchers, and to develop a scientific research 4 .

\section{6-waqf for the centers of rehabilitation of researchers:}

1 Al-Rifāīi, Hasan Mohamad, (1428/ 2007) Al-Waqif 'Alā Mu’asasāt Al-Ta`līmīyyah Kuliyat Al-Taknūlūjiyā Namūzajan, http://iefpedia, p.28-29.

2 Al- 'umrānī, 'Abdullah Mohamed, Dawr Al_waqf fĩ d’am Al-Bahath Al-ilmī (Drasah Fiqhiyyah), p. 4.

3 Al-Mishygih, Khalid Ali, Al-'Awqaf fĩ Al'asr Al-Hadīth Kayf Nuwajihuhā Lida'm wa Tanmiyat Mawāriduhā (Dirāsah Fiqhiyah), http://elibrary.mediu.edu.my/books/SDL2413.pdf, accessed on 22/2/2017 p.36. Al-'umrānī, Dawr Al_waqf fĩ d'am Al-Bahath Al-'ilmī, p. 5. 4 Al-Rifāīi, Al-Waqif 'Alā Mu'asasāt Al-Ta'ïmīyyah Kuliyat Al-Taknūlüjiyā Namūzajan, http:/liefpedia, accessed on 23/2/2017 p.30. Al'umrānī, Dawr Al_waqf fĩ d'am Al-Bahath Al-'ilmī (Drasah Fiqhiyyah), p. 5 
At present, the centers of vocational training and administrative development have emerged significantly. In addition, the higher education institutions need specialized centers in the rehabilitation of researchers in all kind of knowledge to support the educational institutions, and provide the researcher with all skills in the method of contemporary scientific research, technical skills, creative and innovative thinking skills. These centers are funded by endowments 1 .

\section{Conclusion}

Based on the discussion of the subject, the study concluded that:

- Waqf is "the allocation of property (whether moveable and immoveable assets) by the owner for the purpose of benefiting others from it or from its proceeds in any kind of good deeds"

- Waqf had and still has significant role in supporting the field of education and its development in the Muslim world.

- The study is more inclined towards the opinion that argues for the permissibility of cash Waqf and it is considered as contemporary form which can contribute to finance the higher education at the present time.

- It also concluded that Waqf institutions may opt for either of the following for funding higher education:

1. Investing all the cash Waqf and then funding the higher education from the investment's dividends and revenues.

2. Dividing the cash Waqf into two portions, one portion to be invested as a backup and to ensure that continuity of the Waqf, and the other portion is earmarked for funding the higher education.

- Among the contemporary applications of the Waqf is; endowment of the books and computer programs relevant to the research, endowment of libraries and devices, as well as endowment of the centers of rehabilitation of researchers

- The study is more inclined towards the opinion that argues for the permissibility of cash Waqf and it is considered as contemporary form which can contribute to finance the higher education.

\section{References:}

[1] Abū al-Sa'ūd, MohamadMohamad Mustafa, (1417/1997)Risālat al-Nuqūd, Beirut: DārinbHazim.

[2] Al- 'umrānī, 'Abdullah Mohamed, Dawr Al_waqf fĩ d'am Al-Bahath Al-'ilmī (Drasah Fiqhiyyah).

[3] Al-'Abdusalām, Ahmad Sālih, Tārīhk alwaqif 'indalmuslimīn, http://iefpedia

[4] Al-Bahwatī, Mansour Younis, (1416/1996) Sharḥ Muntahā al-Irādāt, Beirut: 'ālamalkutub.

[5] Al-Jamal, Ahmad Mohamad,(1428) the role of the Islamic waqfsystem in contemporary economic development, al qāhirah: Dāralsalām.

[6] Al-Kāsānī, 'āladin Abubakar Mas 'uod, (1418/1997) Badāī' al-Ṣanāï‘, Beirut: Dār al-Kutub al- illmiyah, 3"thd Edition.

[7] Al-Kharshī , Muhammad 'Abdullah 'Alī, (1419/1998) Ḥāshiyat al-Kharshī, Beirut: Dār al-Kutub al-îlmiyah,1 ${ }^{\text {st }}$ Edition.

[8] Al-Kubaysī, Mohamad 'Ubayd, (1397) 'ahkāmal ’awqaffī alshariah, Bagdad: Matbat al-irshad.

[9] Al-Maḥmadī, '́alī Mohamad yousouf, (1422) understanding waqf and its types, paper presented to the first awqāf conference organized by Umm al-Qura university, Mecca.

[10] Al-Mishygih, Khalid Ali, Al-'Awqaf fī Al'asr Al-Hadīth Kayf Nuwajihuhā Lida'm wa Tanmiyat Mawāriduhā (Dirāsah Fiqhiyah), http://elibrary.mediu.edu.my.

[11] Al-Muțīi'T, MohamadNajīb, (1415/1995) Takmilat al-Majmū', Beirut: Dārihya' alturāthal 'arabī.

1 lbid. p.9. 
[12] Al-Rifāīi, Hasan Mohamad, (1428/ 2007) Al-Waqif 'Alā Mu'asasāt Al-Ta'līmīyyah Kuliyat Al-Taknūlūjiyā Namūzajan, http://iefpedia.

[13] Al-Riyadh Newspaper, Issue no. 16111, Ramḍān 1433 A.H./ August 2012.

[14] Al-Shirbīnī, Muhammad al-Khatīb, (1418/1997) Mughnī alMuhtāj ilāma'rifat ma‘ānī alfaz alminhāj, Beirut: Dār al-ma'rifa, 1st $^{\text {Ed }}$ dition.

[15] Al-Thamalī,Abdullah Muslih, cash waqif, http://iefpedia.com/arab/?p=20103.

[16] Al-Zarqā, Mohamad Anis Mustafa, temporary waqf for the financing of small projects for the poor.

[17] Harîīi, the role of wagfin supporting educational, religious, academic and cultural aspects, paper presented to the first awqāfconference organized by Umm al-Qurauniversity in collaboration with the Ministry of Islamic Affairs Awqāf, Da 'wahand Guidance, Mecca, 1422 A.H.

[18] Ibn al-Humām, Muhamad 'Abdulwāhid, Sharḥ Fatḥ al-Qadīr, Beirut: Dār al-Kutub al-îlmiyah, $2^{\text {nd }}$ Edition.

[19] Ibn Mandhūr, Muḥammad Mukrim, (1419/1999) Lisān al-'Arab, Beirut: Dārlhyā' al-Turāth al-'Arabī, $2^{\text {nd }}$ Edition.

[20] Ibn'Abdīn, Mohamad'umar (1419/1998) Rad al-Muhtār'Alā al-Dur al-Mukhtār, Beirut: Dārihya' Alturāthal ‘Arabī,

[21] IbnKhaldun, Muqadimat ibnhkaldun.

[22] IbnQudāmah, al-Maqdisī, (1416/1996) al-Mughnī, alqāhirah: Dār Alhādīth.

[23] Mashhūr, Ni'mat'abdullatîf, (1997) the effect of waqfin the development of society, alqāhirah:.

[24] Qahf, Monzer, Contemporary juristic issues concerning Islamic endowments.

[25] Shalabī, Mohamad, (1402) 'ahkām alwasāyā wa al'awqaf, Beirut: al- Dāraljāmi'iyāhn.

[26] 'Umar, Mohamad abdulhalim, Means of Islamic Financing for small projects, unpublished research paper. 